\title{
Direct versus Indirect Herbicide Effects: The Example of Preplant Incorporated Halosulfuron
}

\author{
Zhenyi Li ${ }^{1}$, Rene Van Acker ${ }^{1}$, Nader Soltani ${ }^{2}$, Peter H. Sikkema ${ }^{2}$ \\ ${ }^{1}$ Department of Plant Agriculture, University of Guelph, Guelph, Canada \\ ${ }^{2}$ University of Guelph, Ridgetown Campus, Ridgetown, Canada \\ Email: soltanin@uoguelph.ca
}

How to cite this paper: Li, Z.Y., Van Acker, R., Soltani, N. and Sikkema, P.H. (2017) Direct versus Indirect Herbicide Effects: The Example of Preplant Incorporated Halosulfuron. American Journal of Plant Sciences, 8, 645-650.

https://doi.org/10.4236/ajps.2017.84044

Received: January 12, 2017

Accepted: February 28, 2017

Published: March 3, 2017

Copyright $\odot 2017$ by authors and Scientific Research Publishing Inc. This work is licensed under the Creative Commons Attribution International License (CC BY 4.0).

http://creativecommons.org/licenses/by/4.0/

\begin{abstract}
The potential indirect effects of soil applied herbicides have not been adequately explored. The objective of this study was to explore the potential and relative importance of the indirect effects of halosulfuron applied preplant incorporated (PPI) on several weed species common in white bean fields in Ontario. Halosulfuron applied PPI at $35 \mathrm{~g}$ ai $\mathrm{ha}^{-1}$ delayed common lambsquarters and wild mustard emergence and reduced their densities over $70 \%$. It did not delay green foxtail emergence, but the density was decreased over $30 \%$. Indirect herbicidal effects such as delayed emergence timing may be important for weed management in non-competitive crops such as white bean. Based on these results, the indirect effects of soil applied herbicides are real and are potentially important for providing additional prevention of yield loss in field crops. This may be particularly important for relatively non-competitive crops such as white bean and for reducing weed seed return to the seedbank.
\end{abstract}

\section{Keywords}

Dry Bean, Halosulfuron, Navy Bean, White Bean, Weed Emergence

\section{Introduction}

After weed density, emergence timing is the most critical determinant of the relative level of weed interference in field crops [1] [2]. Soil applied herbicides could impact both weed density (direct effect) and emergence timing (indirect effect). Effects of herbicides on weed emergence timing (in addition to effects on density) may be important for relatively non-competitive crops, especially those that maintain relatively open canopies such as white bean (Phaseolus vulgaris L.) [3] [4]. White bean yield losses due to weed interference ranged from $58 \%$ to 
$81 \%$ [5] [6] [7]. Halosulfuron is a group 2 herbicide registered for use on white bean in Canada that when applied preplant incorporated (PPI) or preemergence (PRE) controls many annual broadleaf weeds including common lambsquarters (Chenopodium album L.) and wild mustard (Sinapis arvensis L.), but it is less effective on grass weeds including green foxtail (Setaria viridis L.) [5] [6] [7] [8]. Li et al. [6] suggested that halosulfuron applied preemergence had both direct (reduced weed density) and indirect (delayed weed emergence) effects on a range of weed species in white bean. The potential indirect effects of soil applied herbicides have not been explored further.

The objective of this study was to explore the potential and relative importance of the indirect effects of halosulfuron applied preplant incorporated on several weed species common in white bean fields in Ontario.

\section{Materials and Methods}

The six field experiments were conducted at the Huron Research station near Exeter, Ontario (2013 and 2014) and at the University of Guelph Ridgetown Campus near Ridgetown, Ontario (2014). The soils for the two trials near Exeter in 2013 were a Brookston clay loam with $29 \%$ sand, $44 \%$ silt, $27 \%$ clay, $3.6 \%$ organic matter and $\mathrm{pH}$ of 7.7 at site 1 and $18 \%$ sand, $46 \%$ silt, $36 \%$ clay, $4.7 \%$ organic matter and $\mathrm{pH}$ of 7.5 at site 2. The soils for the two trials near Exeter in 2014 were $31 \%$ sand, $42 \%$ silt, $27 \%$ clay, $3.8 \%$ organic matter and $\mathrm{pH}$ of 7.7 at site 3 and $41 \%$ sand, $40 \%$ silt, $19 \%$ clay, $3.3 \%$ organic matter and $\mathrm{pH}$ of 7.7 at site 4. The soils for the two trials near Ridgetown in 2014 were a Fox sandy loam with $50 \%$ sand, $25 \%$ silt, $25 \%$ clay, $2.9 \%$ organic matter and $\mathrm{pH}$ of 7.1 for sites 5 and 6. Seedbed preparation consisted of fall moldboard plowing followed by two passes with a field cultivator with rolling basket harrows in the spring.

The experimental design was a randomized complete block with four replications. Weedy control and halosulfuron applied at $35 \mathrm{~g}_{\text {ai ha }}{ }^{-1}$ PPI were the only two treatments in the experiment. Each plot was $3 \mathrm{~m}$ wide consisting of four rows (spaced $0.75 \mathrm{~m}$ apart) of 'T9905' white bean (obtained from Hensall District C0-operative, 1 Davidson Drive, Hensall, ON, N0M 1X0, Canada). Plots were $10 \mathrm{~m}$ long at Exeter and $8 \mathrm{~m}$ long at Ridgetown. White bean was seeded at a rate of 250,000 seeds $\mathrm{ha}^{-1}$ in late May to early June of each year. Beans were planted on 27 May and 7 June 2013 for site 1 and 2 at Exeter, respectively. In 2014, beans were planted on 4,10,6, and 18 June at sites 3 to 6 at Exeter and Ridgetown. The herbicides were applied on the same day as seeding and were immediately incorporated into the soil to a depth of $5 \mathrm{~cm}$ with two passes (in opposite directions) of an S-tine cultivator with rolling basket harrows. Plots were not irrigated and were fertilized according to Ontario Ministry of Agriculture, Food and Rural Affairs field crops guidelines.

Herbicides were applied with a $\mathrm{CO}_{2}$ pressurized backpack sprayer calibrated to deliver $200 \mathrm{~L} \mathrm{ha}^{-1}$ of spray solution at a pressure of $200 \mathrm{kPa}$ using ULD 120-02 (Hypro, New Brighton, MN) ultralow drift nozzles. The spray boom was $1.5 \mathrm{~m}$ in length with four nozzles spaced $50 \mathrm{~cm}$ apart. 
Weed emergence data were collected weekly from 1 to 10 weeks after crop emergence (WAE) from two $0.25 \mathrm{~m}^{2}$ permanent quadrats in the weedy control and the halosulfuron treatment. Cumulative weed emergence for each week for both treatments was based on total final weed density in the respective experiments. Nonlinear regression was used to fit the following sigmoidal equation to the data:

$$
y=a\left(1-\mathrm{e}^{-b x}\right)^{c}
$$

where $y$ represents percent cumulative weed emergence at weeks after white bean emergence $x$, e is the base of the natural logarithm, and $a, b$ and $c$ are parameters [6]. Regression results were plotted in SigmaPlot v. 12.1 (Systat Software Inc., Chicago, USA). Difference in cumulative weed emergence in the weedy control compared to the halosulfuron treatments was analyzed using a two sample t-test in SAS 9.3 with PROC MIXED (SAS Institute Inc., Cary, NC).

\section{Results and Discussion}

Common lambsquarters emerged earlier in the weedy control than in the halosulfuron treatment (Figure 1(a)). Approximately $86 \%$ to $95 \%$ of the common lambsquarters seedlings emerged in the first 3 or 4 weeks after white bean emergence in the weedy control, which was only $71 \%$ to $79 \%$ in the halosulfuron treatment (Figure 1(a)). Cumulative common lambsquarters emergence in the weedy control and halosulfuron treatment was 16 and 2 plant $\mathrm{m}^{-2}$, respectively which was an $88 \%$ reduction and these densities were significantly different $(\mathrm{P}<$ 0.0001). Wild mustard also emerged earlier in the weedy control than in the halosulfuron treatment (Figure 1(b)). Approximately $85 \%$ to $92 \%$ of the wild mustard seedlings emerged in the first 1 or 2 weeks after white bean emergence in the weedy control, which was only $64 \%$ to $86 \%$ in halosulfuron treatment (Figure 1(b)). Cumulative wild mustard emergence in the weedy control and halosulfuron treatment was 21 and 4 plant $\mathrm{m}^{-2}$, respectively which was an $81 \%$ reduction and these densities were significantly different $(P=0.0018)$. There was no difference in emergence timing of green foxtail between the weedy control and the halosulfuron treatments (Figure 1(c)). Cumulative green foxtail emergence in the weedy control and halosulfuron treatments were 95 and 60 plants $\mathrm{m}^{-2}$, respectively, which was an $37 \%$ reduction and these densities were significantly different $(\mathrm{P}<0.001)$, but represented much lower halosulfuron efficacy than for either common lambsquarters or wild mustard. These results are similar to those reported by Li et al. [6] for halosulfuron applied PRE.

The delay in weed emergence in the halosulfuron treatments was likely the result of the preemergence residual activity of halosulfuron. This is corroborated by the lack of difference in emergence timing for green foxtail which is less susceptible to halosulfuron. For susceptible species such as lambsquarters and wild mustard the preemergence residual activity of halosulfuron may have forced a greater proportion of seedlings to emerge from greater soil depth, which is known to delay weed seedling emergence [9]. 

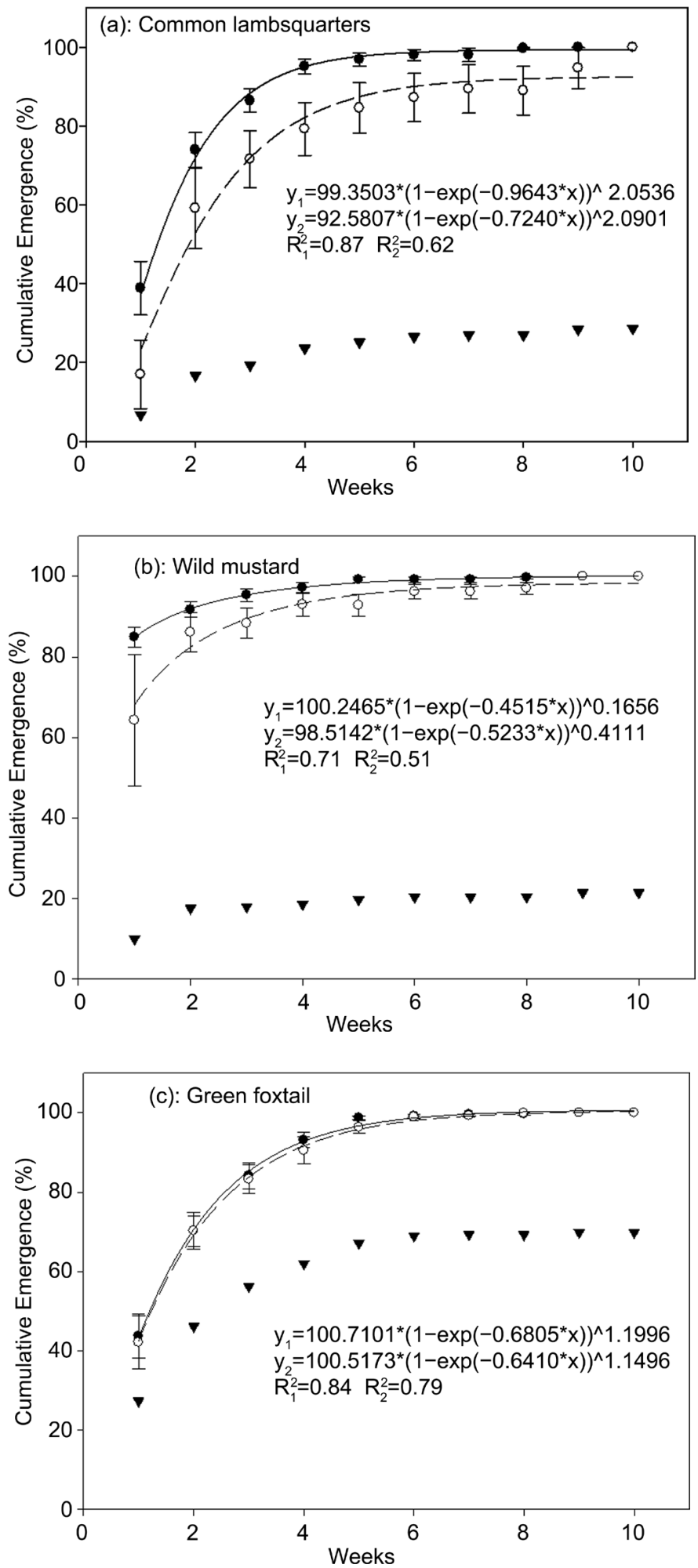

Figure 1. Emergence timing of common lambsquarters (a), wild mustard (b), and green foxtail (c) in white bean in the presence or absence of halosulfuron applied pre-plant incorporated. $(\bullet,-)$ and $\mathrm{y}_{1}$ represent the emergence timing in the weedy control based on final weed density in the weedy control; $(0,-,-)$ and $y_{2}$ represent the emergence timing of weeds in the halosulfuron treatment based on final weed density in the halosulfuron treatment; $\boldsymbol{\nabla}$ represents the percentage of emergence of weeds in halosulfuron based on final accumulative weeds in weedy control. 
The direct effect of halosulfuron applied PPI decreased the density of common lambsquarters and wild mustard more than $70 \%$ and green foxtail more than $30 \%$ (Figure 1). This direct efficacy would provide essential yield protection in white bean [7]. But in addition, the indirect effect, the delayed emergence of lambsquarters and wild mustard would provide additional and possibly substantive additional yield protection. The second trifoliate to first flower stage is the critical period of weed control in white bean in Ontario [10] and weeds appearing after first flower would have no significant effect on white bean yield. Chikoye et al. [4] found that a mere 1.5 common ragweed (Ambrosia artemissifolia L.) seedlings $\mathrm{m}^{-2}$ appearing at the VE (hypocotyl emergence) versus the V3 (third trifoliate leaf unfolded) development stages of white bean resulted in $10 \%$ to $22 \%$ and $4 \%$ to $9 \%$ yield losses, respectively. In this study, most white beans reached VE at 1 WAE and V3 at 3 WAE [4] [11]. Given that these results show that halosulfuron applied PPI caused at least al week delay in emergence for lambsquarters and wild mustard then even the relatively modest indirect effect of halosulfuron witnessed could substantively reduce yield loss potential in white bean. In addition, Chikoye et al [4] reported that a 2 week delay in common ragweed emergence resulted in significantly less weed seed production [4]. When applied PRE, Li et al. [6] [7] found that halosulfuron reduced the dry weight of common lambsquaters and wild mustard by more than $99 \%$ compared to the weedy control suggesting that the weeds that do emerge late and survive would likely not produce substantive amounts of seed [6] [7].

\section{Conclusion}

The results of this work show that the indirect effects of soil applied herbicides are real and are potentially important for providing additional prevention of yield loss in field crops. This may be particularly important for relatively noncompetitive crops such as white bean and for reducing weed seed return to the seedbank.

\section{References}

[1] Van Acker, R.C. (2009) Weed Biology Serves Practical Weed Management. Weed Research, 49, 1-5. https://doi.org/10.1111/j.1365-3180.2008.00656.x

[2] Nazarko, O.M., Van Acker, R.C. and Entz, M.H. (2005) Strategies and Tactics for Herbicide Use Reduction in Field Crops in Canada: A Review. Canadian Journal of Plant Science, 85, 457-479. https://doi.org/10.4141/p04-158

[3] Malik, V.S., Swanton, C.J. and Michaels, T.E. (1993) Interaction of White Bean (Phaseolus vulgaris) Cultivars, Row Spacing, and Seeding Density with Annual Weeds. Weed Research, 41, 62-68.

[4] Chikoye, D., Weise, S.F. and Swanton, C.J. (1995) Influence of Common Ragweed (Ambrosia artemisiifolia) Time of Emergence and Density on White Bean (Phaseolus vulgaris). Weed Research, 43, 375-380.

[5] Soltani, N., Nurse, R.E., Shropshire, C. and Sikkema, P.H. (2014) Weed Control in White Bean with Various Halosulfuron Tankmixes. Advances in Agriculture, 2014, Article ID: 391634. https://doi.org/10.1155/2014/391634 
[6] Li, Z., Van Acker, R.C., Robinson, D.E., Soltani, N. and Sikkema, P.H. (2016) Halosulfuron Tank-Mixes Applied PRE in White Bean. Weed Technology, 30, 57-66. https://doi.org/10.1614/WT-D-15-00084.1

[7] Li, Z., Van Acker, R.C., Robinson, D.E., Soltani, N. and Sikkema, P.H. (2016) Halosulfuron Tankmixes Applied Preplant Incorporated for Weed Control in White Bean (Phaseolus vulgaris L.). Canadian Journal of Plant Science, 96, 481-88. https://doi.org/10.1139/cjps-2015-0124

[8] Brown, D. and Masiunas, J. (2002) Evaluation of Herbicides for Pumpkin (Cucurbita spp.). Weed Technology, 16, 282-292. https://doi.org/10.1614/0890-037X(2002)016[0282:EOHFPC]2.0.CO;2

[9] Bullied, W.J., Marginet, A.M. and Van Acker, R.C. (2003) Conventional- and Conservation-Tillage Systems Influence Emergence Periodicity of Annual Weed Species in Canola. Weed Science, 51, 886-897. https://doi.org/10.1614/P2002-117

[10] Woolley, B.L., Micheals, T.E., Hall, M.R. and Swanton, C.J. (1993) The Critical Period of Weed Control in White Bean (Phaseolus vulgaris). Weed Science, 41, 80184.

[11] Li, Z. (2016) Halosulfuron: Crop Tolerance, Weed Control and Species Sensitivity in Dry Beans. PhD Thesis, University of Guelph, Guelph.

Submit or recommend next manuscript to SCIRP and we will provide best service for you:

Accepting pre-submission inquiries through Email, Facebook, LinkedIn, Twitter, etc. A wide selection of journals (inclusive of 9 subjects, more than 200 journals)

Providing 24-hour high-quality service

User-friendly online submission system

Fair and swift peer-review system

Efficient typesetting and proofreading procedure

Display of the result of downloads and visits, as well as the number of cited articles

Maximum dissemination of your research work

Submit your manuscript at: http://papersubmission.scirp.org/

Or contact ajps@scirp.org 